\title{
Introduction:
}

\section{Impact of C. Vann Woodward's The Burden of Southern History}

\section{Angie Maxwell}

In the Spring of 2010, the Diane D. Blair Center of Southern Politics and Society of the University of Arkansas, in partnership with the Winthrop Rockefeller Institute, held the Third Annual Blair-Rockefeller Legacy Series Conference. The interdisciplinary symposium explored the ongoing impact of southern historian C. Vann Woodward's The Burden of Southern History, which was published in 1960. In conjunction with the conference, the American Review of Politics issued a call for articles that interrogate Woodward's key ideas in a twenty-first century context. Woodward tackles questions of equality, white southern identity, the political legacy of reconstruction, the heritage of populism, the place of the South within the nation, among other topics.

\section{Contributions and Contributors}

The three articles that comprise this special issue all explore C. Vann Woodward's vision of the American South. In The Burden of Southern History, Woodward, who confessed to being an activist historian, attempted to broaden the definition of southern identity. His private goal was to refocus southern whites on elements of their identity that did not rely solely on the maintenance of white supremacy and segregation. Woodward, for example, investigated the agricultural roots of the South, as well as the political impulse towards Populism that swept through the region at the dawn of the 20th century. In their contribution to this special issue, "When White Goes Right: The Old South in the 2008 Presidential Election,” Matt Fowler, Wayne Parent, and Peter Petrakis attempt to quantify these unique characteristics of southern white identity. Fowler, Parent, and Petrakis note the hegemonic nature of southern voting patterns (barring the change in party label that realigned the region with the Republican Party), arguing that the 2008 Democratic victories in North Carolina, Virginia, and Florida, provides an opportunity to analyze what may be a "shrinking South." They provide a

\footnotetext{
ANGIE MAXWELL is the Diane D. Blair Professor of Southern Studies and an Assistant Professor of Political Science at the University of Arkansas.
}

The American Review of Politics, Vol. 32, Summer, 2011: 79-81

(C)2011 The American Review of Politics 
rich historical context for these markers of southern identity, returning specifically to W.J. Cash's "proto-dorian bond," a phrased coined in his 1941 book, The Mind of the South. Their innovative effort to make tangible the intangibles of southern white identity offers future scholars new tools through which to reconsider the political nature of the American South.

Hanes Walton, Jr., Josephine A.V. Allen, Sherman C. Puckett, and Donald R. Deskins, Jr., undertake a detailed and nuanced investigation of what Woodward called the "Third Reconstruction" in revised editions of The Burden of Southern History. Writing after the death of Martin Luther King, Jr. in 1968, Woodward called for a new wave of civil rights reform-one that would move past the violence and "tokenism" that failed to produce true change. Walton et al., in a vein similar to Fowler, Parent, and Petrakis, attempt not only to define this "Third Reconstruction," but also to quantify and measure its progress in America. Specifically, in their article, entitled "Beyond the Second Reconstruction: C. Vann Woodward's Concept of the Third Reconstruction in the South," the authors analyze the success of African American presidential campaigns, including those launched by Jesse Jackson, Shirley Chisholm, and, most recently, Barack Obama.

In his article, "Racism, Resentment, and Regionalism: The South and the Nation in the 2008 Presidential Election,” Joseph Aistrup, ironically, finds that very racial attitudes against which Woodward fought, exist and continue to influence elections. While Walton et al. reconsider the regional response to Black presidential candidates over time, Aistrup focuses on the 2008 election of Barack Obama, comparing regional and national responses to this historic candidate. And clearly Aistrup's findings point to little for Woodward to be proud of in the South and the country at large. Despite the half century that has passed since Woodward's volatile collection first appeared, the ideas that leap from every page remain, for the most part, the debates that still drive the study of the South among countless disciplines, including political science. The efforts of these scholars to interrogate such fluid concepts as racism and identity advance our understanding of the distinctiveness of this region and its place within the every-changing American political landscape. The ideas presented here should spur research projects for years to come.

\section{The Diane D. Blair Center of Southern Politics and Society}

The Blair Center, directed by Todd G. Shields, was established by an act of U.S. Congress in the fall of 2001, making it one of the rare research centers in the country to be created by congressional appropriation. Diane Divers Blair taught in the Department of Political Science at the University of Arkansas for thirty years, receiving designation as Master Teacher in 
1982 and being named the university-wide Outstanding Faculty Member three times. Her career outside of teaching included extensive public service as chair of both the U.S. Corporation of Public Broadcasting and the Commission on Public Employee Rights. She was also a founding member of the University of Arkansas Press. In 1992 she joined the Clinton presidential campaign as a senior researcher, after which she was appointed a guest scholar at the Brookings Institute. She returned in 1996 as a senior advisor on the Clinton re-election team. Her publications include Silent Hattie Speaks: The Personal Journals of Senator Hattie Carraway (Greenwood Press, 1979), Arkansas Politics and Government: Do the People Rule? (University of Nebraska Press, 1988), as well as fourteen book chapters and over ninety additional articles.

Diane D. Blair was equally committed to scholarly research as she was to public activism, as is witnessed by her personal and career achievements. Moreover, she was a champion of interdisciplinary methods and critical thinking and she reached across the academic aisles often and with ease. The Blair Center reflects her intellectual approach and strives to view the American South from a variety of angles in order to reveal the undercurrents of politics, history, and culture that have shaped the region over time. The Blair Legacy Series invites senior scholars to assess the regional, national, and international impact of southern politicians, intellectuals, and social leaders.

\section{The Rockefeller Institute}

The Rockefeller Institute, also part of the University of Arkansas System, is an educational institute and conference center located on Petit Jean Mountain. The 188-acre campus was once part of the home and cattle farm of Governor Winthrop Rockefeller, giving it a remarkably distinguished heritage on which to build. In the 20 years he lived at Winrock Farms, Rockefeller hosted more than 200 conferences and meetings-conclaves that addressed an astonishing range of concerns, from educational needs and rural economic development, to how to build Arkansas and harmonize the races. Today, the Institute continues to build upon the legacy of its namesake by providing an environment conducive to open discussion, for stimulating new perspectives, and for developing future-oriented results. 